
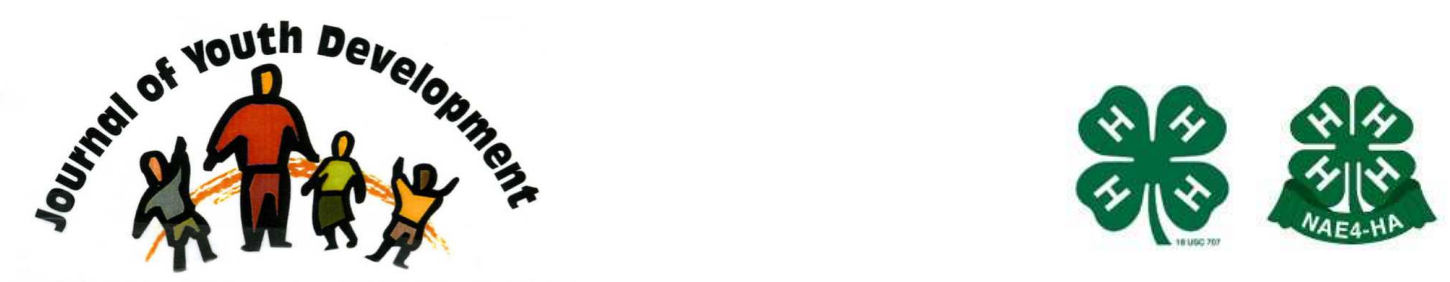

Bridging Research \& Practice

\title{
Fertile Ground: Assessing the Public Library as a Context for Preparing Youth for Community Engagement
}

\author{
Kenneth R. Jones \\ University of Kentucky \\ Lexington, $\mathrm{KY}$ \\ kenrjones@uky.edu
}

\author{
Terrence J. Delahanty \\ Independent Consultant \\ Louisville, KY \\ tjpd@lycos.com
}




\title{
JOURNAL OF YOUTH DEVELOPMENT \\ bridging research and practice

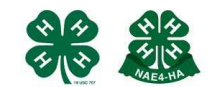

Volume 6, Number 1, Spring 2011

Article 110601FA002

\section{Fertile Ground: Assessing the Public Library as a Context for Preparing Youth for Community Engagement}

\author{
Kenneth R. Jones \\ University of Kentucky \\ Terrence J. Delahanty \\ Independent Consultant
}

\begin{abstract}
Libraries provide settings where youth can experience positive development. However, many young people and their families do not access the potential these institutions afford their communities. In addition, library staff are seldom presented with opportunities to work more intimately with young people visiting the library. This article provides data on library staff and their feelings toward youth and their experiences interacting with young people in their local libraries. The findings of the study reveal that library staff members have an array of perceptions toward young people and how youth can be affected.
\end{abstract}

\section{Introduction}

Research studies and evidence-based evaluations have revealed that youth development occurs regardless of a child's situation or the place of residence, whether in a positive or negative atmosphere. Families, youth-serving agencies and communities reserve the right to ensure that young people have affirming experiences throughout the developmental stages. This is most likely to occur within settings where youth are nurtured and feel welcomed.

According to a 2002 commentary by Pittman and Yohalem, there is a trend to enlist community assets as a means to support young people in their educational pursuits and development. For communities, the most logical conclusion is to utilize those facilities where young people congregate, and more specifically, those places offering varied forms of education and civic engagement opportunities within a safe environment. However, venues that support out of school time are limited in many communities, at a point when they are desperately needed the most. Studies show that youth involved in structured out of school time receive less exposure to risk factors, fewer chances to engage in sexual activities and less inclined to become victims of crime (Little, Wimer \& Weiss, 2008; Newman, Fox, Flynn, \& Christeson, 2000). The challenge remains in going beyond a prevention approach to present youth with access to opportunities 
that can determine more success in their lives. This must commence with places serving as positive settings that welcome, affirm and nurture the developmental need of the young people who frequent their facilities.

Over the past several years, a number of assessments have been conducted to determine the needs of young people when they are not in school (i.e., after school, summer). One of the more comprehensive reports emerged more than a decade ago when the Carnegie Council on Adolescent Development published the report, $A$ Matter of Time (1992), which revealed what young people wanted during out-of-school time. The report included national data which revealed that America's youth have stressed the importance of having stronger connections with caring adults, more opportunities to give back to their communities, protection from drugs and violence and be afforded more meaningful experiences in the non-school hours. Although programs are quintessential in achieving these goals, the majority of the data revealed that youth suggested the importance of having places to go in order to meet their social, cultural, and educational needs (Forum for Youth Investment, 2005).

Schools are inherently the premier source for providing a structured environment for learning. However, youth development is not confined to four walls; yet it is a constant process that occurs over a significant period of time. In order for youth to gain those protective factors that are pertinent to achieving mastery in social skills, self-efficacy, and academic prowess, youth development professionals must consider all resources within a community to make sure young people have access to positive youth development. That is, all of the resources necessary for youth to move from childhood into productive responsible adulthood. It has been well documented that youth should have a role in this process, preferably in the form of decisionmaking within their communities.

Most young people (particularly teens) are very much aware of the social ills that plague their families and community. However, having a chance to become civically engaged within the community is often nullified by a lack of opportunities and places to provide a forum for youth decision-making. Moreover, the negative perceptions of adults often propose the largest barrier. This article highlights the perceptions staff working at community-based libraries have about youth. The authors provide insight on how the attitudes of these individuals can play a part in discouraging youth from taking advantage of the resources offered through community-based libraries. An additional emphasis is also placed on the role specific interactions between adult library staff and young people who frequent libraries can play to curb negative perceptions. The purpose of this article is to stimulate further discussion on the importance of making sure youth are solicited as stakeholders in community development, with local libraries being considered as a common place that nurtures the process.

\section{Literature Review}

Young people comprise a significant percentage of public library patrons. National data has reported that at least $65 \%$ of library users are ages 18 and under, with $23 \%$ within the range of 12 to 18 years of age (National Center for Educational Statistics, 1995). Young people (more specifically, teens) are coming to the library more often and staying longer. Hence, they are flocking to libraries for reasons far beyond the traditional usage, such as checking out books. Libraries serve as a prominent location for free access to computers and the internet. Young people are coming to the library more to complete homework, conduct research and connect with peers (whether face to face or via social networking websites). In addition, because libraries tend to be located in or near neighborhoods and within walking distance from homes 
and schools, they have become popular places to "hang out." However, for some areas, this has served as a contrast for fostering youth development. Some libraries have viewed the gathering of youth more as loitering and not the positive peer interaction that is pertinent to social skill development. As a result, several have responded by closing down early. According to a New York Times article (Kelley, 2007), a New Jersey Public library closed its doors from 2:45 to 5:00 P.M. in direct response to "rowdy teenagers." Although some young people can exhibit behavior problems, this mode of operation can put up hurdles that deprive deserving youth of opportunities that can promote positive development within their communities.

In the past, research has documented the needs of youth in our society. If young people are going to become productive adults, there must be certain features and settings in place to ensure that they have what is necessary to become competent citizens. Eccles \& Gootman (2002) presented a list of features that maximize positive development within families, schools, neighborhoods and community-wide programs. As many scholars have revealed, it is important to intentionally consider all of these contexts, for each is unique in its inclusivity and influence of youth in some way. Youth interact within these various settings, invoking youth development to occur as a natural process. Eccles \& Gootman (2002) noted the settings specifically as physical and psychological safety, appropriate structure, supportive relationships, opportunities to belong, positive social norms, support for efficacy and mattering, opportunities for skill building, and integration of family school and community efforts. All of these entities are provided through the services that can be accessible to youth via local libraries.

Most libraries are considered as designated safe places, a key element for youth to experience positive interactions and engage in skill building. Furthermore, libraries provide a structured environment that is conducive, not only to learning, but also in promoting a sense of community. All typically have clear rules that feed into positive social norms, which in turn, help youth learn of ways to govern behavior. Moreover, when serving as a synergistic tool between systems that serve young people, all of the aforementioned settings (see Eccles \& Gootman, 2002) provide the best experiences for youth. As civic institutions within communities, libraries offer a place of developmental resources and assets that youth can draw upon to cultivate the skill sets needed to effectively participate in today's society (Benson, 1997; Moellman \& Tillinger, 2004). This may include engaging in supportive relationships with adults who assist youth in acquiring the proficiency to serve their communities. With the wealth of information, youth are also at liberty to learn more about their community in general, thus generating thriving prosocial behaviors that demonstrate neighborhood pride. Researchers have reported that the more community based programs (such as those available at libraries), the longer the effects of protective factors abound, much more than what school-based programs could achieve alone (Dryfoos, 2000). Hence, integrating community-based services to promote youth development may repel some of the detriments that can result in a host of problem behaviors. Therefore, utilizing the local library to foster a sense of community connectedness is a worthwhile endeavor.

In 1998, the Dewitt Wallace-Reader's Digest Fund (in collaboration with the American Library Association), put forth a new initiative to assist public libraries in developing programs and activities that work in tandem with organizations to provide services and support systems for youth. A national survey was mailed to 1500 public libraries in the United States serving populations of 100,000 or more. There was an $83 \%$ response rate with all but a few of the libraries indicating that they offered programs for school-age youth (American Library Association, 1999). Data gathered included information on six common types of programs: Reading programs (99.6\%); Cultural programs (82\%); Community service/leadership programs 
(42.2\%); Computer classes (33.2\%); Homework assistance (23.4\%), and; Career development $(19.2 \%)$. A majority of the responses indicated that libraries expected to serve more youth during the following year. The data also revealed that most of the public libraries collaborated most often with schools and local organizations to promote youth programming.

Unfortunately, there is a frequent disconnect between youth and adults due to low levels of interaction and stereotypical views. Gilliam and Bales (2001) found that adults view teens through their own lens, thus comparing them to their adolescent experience. They believe today's teens are without the values of those in the past and often associate youth with negative trends. Lee, Farrell, and Link (2004) also found supporting evidence that the media serves as a driving force, feeding the minds of adults with negative images about today's youth. Research studies have provided strong evidence that adult perceptions of youth are often negative and may impact the rate at which young people engage in opportunities within the community. Jones and Perkins (2006) reported that adults with positive perceptions of youth can engage youth in specific issues, thus energizing youth to contribute to their communities and become more assertive in reaching their full potential. However, young people must have access to places that offer an environment with caring adults who are willing to foster their healthy development (Rhodes, 2002). Places of consideration should include those that can encourage youth to become more knowledgeable and civically-engaged. Libraries provide a fertile ground to expose adults to the power of youth whether by allowing them to work together as partners or by serving youth through program efforts.

\section{Purpose of the Study}

This study was developed to assess the perceptions library staff members have toward youth within their (library's) communities. The desired outcomes of the study aimed to:

- raise awareness among library staff and to increase their understanding and knowledge of young people;

- increase individual capacity by encouraging positive interaction between youth and adults, and;

- create positive experiences for youth in the public libraries by offering a welcoming environment that serves as a source for generating a sense of community among young people.

The population consisted of staff from public libraries throughout a state of the southern United States. Participants were identified with the assistance of the state's Department of Libraries and Archives. The research agenda included conducting an assessment to measure perceptions toward young people, connections with young people at the library and rating the level of support for young people. Participants from local public library branches included: reference librarians, library assistants, supervisors, and directors. A majority of the libraries represented in the study were located in rural areas, although a few were located in urbanized areas.

\section{Methodology}

The survey instrument used to gather data was developed and pilot-tested using 32 library staff members that were not participants of this study. The survey assessed four attitudinal constructs: Support for Young People in the Community; Youth in the Community; The Local Library as a Youth-Centered Environment; and Personal Connections with Youth. A pilot test was conducted to determine the reliability of the instrument, yielding the following Cronbach coefficient results: Support for Young People (.84); Youth in the Community (.84); Local Library 
as a Youth-Centered Environment (.89), and; Personal Connections with Youth (.71). Expert criterion validity was employed by using a panel of experts (including employees of the state's Department of Libraries and Archives). The panel was also assembled to determine levels of cultural sensitivity and content validity of the survey.

Participants (i.e., library staff) from 61 public libraries were surveyed over the course of six months, with a total of 239 participants completing the survey. A majority of the sample consisted of Whites (84\%), followed by African American (6\%), Hispanic/Latino (1.7\%), Asian $(1.3 \%)$, Native American (0.4\%). Most ( $80 \%)$ of the participants were females. A majority (72\%) of the participants had pursued education beyond high school, obtaining an associate's degree or higher. More than $80 \%$ were over the age of 30 , having a minimum of $1-3$ years of experience as librarians. Over $67 \%$ lived and worked in the same community. Additional demographics are included in Table 1.

Table 1

Demographics

\begin{tabular}{|c|c|c|}
\hline Demographics & $\mathbf{n}$ & $\%$ \\
\hline $\begin{array}{l}\text { Tenure with Current Job } \\
\text { Less than } 1 \text { year } \\
1-3 \text { years } \\
4-9 \text { years } \\
10-15 \text { years } \\
\text { Over } 15 \text { years } \\
\text { No Response }\end{array}$ & $\begin{array}{l}28 \\
68 \\
74 \\
26 \\
34 \\
9\end{array}$ & $\begin{array}{l}11.7 \\
28.4 \\
30.9 \\
10.8 \\
14.2 \\
4.0\end{array}$ \\
\hline $\begin{array}{l}\text { Length of time living in current community } \\
\text { Less than } 1 \text { year } \\
1-3 \text { years } \\
4-9 \text { years } \\
10-15 \text { years } \\
\text { More than } 15 \text { years } \\
\text { No Response }\end{array}$ & $\begin{array}{l}10 \\
26 \\
43 \\
31 \\
126 \\
3\end{array}$ & $\begin{array}{l}4.2 \\
11.0 \\
18.2 \\
13.1 \\
53.4 \\
0.1\end{array}$ \\
\hline $\begin{array}{l}\text { Job responsibility of working directly with } \\
\text { youth? } \\
\text { Yes } \\
\text { No } \\
\text { No Response }\end{array}$ & $\begin{array}{l}201 \\
34 \\
4\end{array}$ & $\begin{array}{l}84.1 \\
14.2 \\
1.7\end{array}$ \\
\hline $\begin{array}{l}\text { Library has teen advisory board } \\
\text { Yes } \\
\text { No } \\
\text { No Response }\end{array}$ & $\begin{array}{l}88 \\
139 \\
12\end{array}$ & $\begin{array}{l}36.8 \\
58.2 \\
5.0\end{array}$ \\
\hline $\begin{array}{l}\text { Number of youth observed using the library in } \\
\text { a given week? } \\
\text { None } \\
1-25 \\
26-50 \\
51-75 \\
76-100 \\
\text { Over } 100 \\
\text { No Response }\end{array}$ & $\begin{array}{l}2 \\
40 \\
52 \\
51 \\
23 \\
57 \\
14\end{array}$ & $\begin{array}{l}0.8 \\
16.7 \\
21.7 \\
21.4 \\
9.7 \\
23.8 \\
5.9\end{array}$ \\
\hline
\end{tabular}




\section{Results}

The attitudinal constructs were based on a scale from 1 to 5, with 1 being "strongly disagree" and 5 being "strongly agree." Participants were fairly neutral on all constructs relating to their perceptions of youth in their communities. Library staff viewed support for youth in the community at 3.04 (on a 5-point scale). Items used to measure this construct included: "There is an adequate amount of support systems for youth," "Adults provide positive supportive environments," and "Parents support efforts that encourage youth to do well in school." When asked about the perceptions of youth in general, participants had slightly less than neutral perceptions (2.96). Some items used to comprise this construct included: "Youth in the community make good leaders," "Youth are very responsible," "Youth are motivated to excel," and "Youth are interested in helping to improve the community." When reporting on whether the library in which they work incorporates youth-centered principles, staff had more positive perceptions (mean $=3.56$ ). They agreed to specific items such as: "Our library is a part of young peoples' lives," "Our library provides a safe environment for youth," "We provide programs of interest to youth," and "We value youth as a part of our mission." Lastly, in assessing their personal connections with youth, library staff remained neutral (3.00). Items used to create this construct included: "I work well with young people," "I fully understand youth in this community," and "I enjoy interacting with young people." Table 2 shows the means of participants' responses.

Table 2

Perceptions of Library Staff toward Youth in the Local Library $(n=239)$

\begin{tabular}{|l|l|l|}
\hline Construct & Mean & S.D. \\
\hline Support for Youth in the Community & 3.04 & .48 \\
\hline Perceptions towards Youth in the Community & 2.96 & .43 \\
\hline Library has a Youth-Centered Focus & 3.56 & .55 \\
\hline Personal Connections with Youth & 3.00 & .56 \\
\hline
\end{tabular}

Note. Scale: 1= strongly disagree; 2=disagree; 3=neutral; 4=agree; 5= strongly agree

Table 3 provides survey data on the comparison between those library staff members who had youth councils in their libraries and those without councils. These councils varied in levels of responsibility. Some staff reported that their council helped with duties, such as organizing youth programs at the library, while other councils served as a library outreach component to aid the larger community (e.g., assist with neighborhood clean-ups, conduct food drives for needy families). A series of independent t-tests were conducted to compare those libraries with youth councils to those without councils. The analyses revealed a statistically significant difference between those libraries that had a youth-centered focus (3.81 vs. 3.50). Those library staff members at libraries with youth councils were more positive towards their role in providing youth with opportunities and support systems. 


\section{Table 3}

Perceptions of Staff with Councils and those without Councils

\begin{tabular}{|l|l|l|l|l|l|l|}
\hline Support for Youth in the Community \\
\hline & $\mathrm{n}$ & Mean & S.D. & $\mathrm{t}$ & $\mathrm{df}$ & $\mathrm{p}$ \\
\hline $\begin{array}{l}\text { Libraries with Youth } \\
\text { Councils }\end{array}$ & 36 & 3.16 & .39 & 1.68 & 131 & .09 \\
\hline $\begin{array}{l}\text { Libraries with no Youth } \\
\text { Councils }\end{array}$ & 97 & 3.01 & .46 & & & \\
\hline Perceptions toward Youth in the Community & & & \\
\hline Youth Council & 36 & 3.02 & .34 & .117 & 131 & .90 \\
\hline No Youth Council & 97 & 3.01 & .41 & & & \\
\hline Libraries having a Youth-Centered Focus & & & \\
\hline Youth Council & 36 & 3.81 & .37 & 3.81 & 93.85 & $.00 *$ \\
\hline No Youth Council & 97 & 3.50 & .53 & & & \\
\hline Personal Connections with Youth & 36 & 3.64 & .62 & .66 & 132 & .53 \\
\hline Youth Council & 36 & .52 & & & \\
\hline No Youth Council & 97 & 3.57 & & & & \\
\hline & & & & & \\
\hline
\end{tabular}

Note. ${ }^{*} p<.001$

Since one purpose of this study was to examine the influence of perceptions on youth in communities, data were examined to determine if specific demographic variables influenced perceptions. Regression analyses were used to compare library staff based on the following independent variables: age; years of experience; length of time living in their community; whether or not they live and work in the same community; having responsibility of working directly with youth; and youth council vs. no youth council.

Table 4

Standardized Regression Coefficients for Library Staff Perceptions of Youth in the Community

\begin{tabular}{|l|l|l|l|l|l|l|}
\hline & \multicolumn{2}{|l}{ Support for Youth } & \multicolumn{2}{l|}{$\begin{array}{l}\text { Youth-Centered } \\
\text { Libraries }\end{array}$} & \multicolumn{2}{l|}{$\begin{array}{l}\text { Personal } \\
\text { Connection with } \\
\text { Youth }\end{array}$} \\
\hline & $\beta$ & $(\mathrm{SE})$ & $\beta$ & $(\mathrm{SE})$ & $\beta$ & $(\mathrm{SE})$ \\
\hline Age & -.052 & .074 & -.041 & .081 & -.102 & .086 \\
\hline Years of Experience & -.085 & .075 & -.046 & .082 & -.134 & .086 \\
\hline $\begin{array}{l}\text { Time Living in } \\
\text { Community }\end{array}$ & .092 & .075 & .048 & .082 & .074 & .085 \\
\hline $\begin{array}{l}\text { Live/work in } \\
\text { Community }\end{array}$ & .026 & .071 & .010 & .078 & .121 & .081 \\
\hline Work with Youth & .124 & .094 & .257 & $.105^{*}$ & .295 & $.105^{* * *}$ \\
\hline Youth Councils & .168 & $.067^{*}$ & .344 & $.073^{* *}$ & .038 & .076 \\
\hline & & & & & & \\
\hline $\mathrm{N}$ & 205 & & 207 & & 209 & \\
\hline
\end{tabular}

Note. ${ }^{*}=p<.05 ; * *=P<.001 ; * * *=p<.01$

Only one factor (Libraries with youth councils) was found to be a significant predictor in a hierarchical regression model for the construct, Support for Youth. Library staff who reported having a youth council at their library had more positive perceptions of there being a high level 
of support for youth in their community. When determining whether the library was youthcentered, thus providing a youth-friendly atmosphere, there was a more positive association stemming from staff who had youth councils in place and who work directly with youth as one of their job responsibilities. Together, these predictors explained $12 \%$ of the variance, that local libraries provide opportunities and support systems for youth. There was also a positive relationship between those staff members who have the responsibility of working directly with youth and their perception of having a personal connection with young people. In summary, staff who worked directly with youth were more likely to work in libraries that present a youthcentered environment. They also expressed having stronger connections with young people. There were no significant predictors revealed when examining staffs' general perceptions of youth in the community.

\section{Conclusion}

The findings of this study revealed that library staff members have an array of perceptions toward young people. Based on the attitudinal constructs, library staff were consistent in their neutral feelings toward youth in the community, as well as their experiences interacting with young people in the local libraries. Although they had positive perceptions toward the services they provide to young people within their libraries, they indicated less positive perceptions toward youth in general. This resonates with the work of scholars who have argued how perceptions can aid or hinder the youth development process for young people.

The attitudes of library staff can play a significant role in helping youth to perceive the local library as a part of their community where they have access to meaningful opportunities. Young people make up the ecological stratum that compiles the complexities of a community. The time is now to search for ways to support their development by utilizing local resources as tools that enhance their lives. Libraries are local resources with a mission to serve all members of the community and a place that can be an important and positive developmental setting for young people. Hence, these facilities provide physical and psychological environments that are safe and supportive. The next step is for libraries to intentionally create opportunities for positive interaction and engagement. Many libraries already have plans in place to promote citizenship, while others are establishing the partnerships and staff capacity building essential for achieving desired outcomes. With libraries serving as valued commodities in most communities, there is the potential for significant change when they are intentional about affording young people the chance to engage in purposeful roles in the library and the community.

One of the most prominent factors found to serve as a predictor included those staff members who worked directly with youth. Staff who worked directly with youth were more positive towards two attitudinal constructs. Moreover, they believed that they provided a youth-centered atmosphere and had stronger personal connections with those young people using the library. This relates to previous findings in the literature which indicates that when youth and adults have opportunities to work together, positive perceptions flourish (Jones, 2006). Such evidence also connects with the research around intergroup contact theory (Allport, 1954), which argues that when community residents come together to connect on comparable ideas, they begin to see that they have more commonalities than differences (Hewstone, 1996; Pettigrew, 1998). Therefore, relationships for youth and adults to interact in positive and meaningful ways are nurtured. This can be as rudimentary as events integrated into existing programs such as youth advisory councils, youth library internships, community service projects and youth-led learning opportunities. 
Findings also revealed that libraries with youth councils had more positive staff. These participants indicated more positive views in providing a youth-focused library environment than those libraries without youth councils. Youth councils were not the same at each library. However, most of the councils were in place for youth to offer some direction to the staff on how to provide opportunities for youth. It is understandable why these staff members would be more positive; for they are going directly to the source (young people) to discover their needs. These councils also give young people a chance to utilize their skills during out-of-school time, instead of providing them with no constructive activities in the libraries. This helps to negate the pessimistic feelings that adults may have toward youth "hanging out" in the library. Hence, libraries empower youth to do something constructive that is witnessed by the entire community. These same opportunities can also offer young people outlets that abate the negative perceptions and behaviors that can occur when no structure is in place.

Encouraging stronger, positive interactions may develop through youth-adult relationships, which can, in turn, be worthwhile endeavors at local libraries. This was evident among those staff persons who worked directly with youth, as well as those libraries with youth councils. One strategy to promote stronger relationships that can aid community development is to incorporate youth in the decision-making process. At the same time, it's critical to keep in mind that the power sharing may be a challenge for adults. Although the body of literature on the benefits of youth-adult partnerships and what is learned through these collaborations has expanded, there remains a need to conduct studies and promote innovative practice that provide solutions to understanding how youth and adults can work together on behalf of their communities (Zeldin, Camino, \& Mook, 2005). One strategy is by educating those that work with youth, whether directly or indirectly. Many library systems are making a commitment to providing training and development for all ranges of library staff to increase their knowledge and skills in working with and empowering youth. In the state participating in this study, the Department for Libraries and Archives contracted with a youth development training organization to deliver twelve hours of hands on training for over 400 public library staff across the state. Participants ranged from library directors to security and janitorial staff.

Although this study did not explore additional challenges affecting libraries based on location or assets, many of the more rural and older libraries typically have limited resources and therefore do not have the space or time to dedicate adequate opportunities that engage young people in community affairs at higher levels. Many have to operate on budgets where they meet the immediate needs of residents (e.g., providing reading/reference materials, access to the internet) with little efforts allotted towards providing services that promote community empowerment. However, it does not inhibit space or time to invest in transforming a library into a positive youth-centered setting. Yet, it requires a commitment from all stakeholders, from board members to staff, that are earnest about the developmental needs of the young people who walk through their doors.

Staff development is critical if libraries are to accept the call as a salient contributor to youth development within a community context. As with any environment where youth-adult interaction ensues, the library in itself is another example of a community where many adults distance themselves from their memories incurred during the adolescent years. Hence, some staff may have a hard time understanding today's young person. Add in the societal changes and technological advances teens have so readily adapted and therein provides a significant number of adults who impose a level of discrimination towards youth by treating them differently than other library patrons. As previous studies have shown, more research and practical strategies are needed to reverse the lack of knowledge that exists among library staff 
to communicate and connect with youth. In order for communities to empower young people, there must be at least a willingness to embrace youth culture.

\section{Recommendations}

A community core is not complete without a library, which is known to serve youth and therefore should consider services that afford a chance for young people to come together to help themselves and even more so, their community. Libraries can serve in various capacities, from a meeting space for youth clubs to serving as the headquarters of a community youthadult taskforce poised to address critical issues. When considering youth gaining exposure to citizenship, structured formal environments have been held in high regard as the means to teach students about the importance of civic awareness. However, in order to be effective in community affairs, the most sufficient preparation has normally provided hands-on experiences occurring within non-formal or informal settings. Young people do not experience frequent training in community organizing. Ironically, many of today's youth are driven by a desire to make a difference. Local libraries within the neighborhoods can serve that purpose for such an educative experience. Below are a few recommendations when considering libraries as a vessel for strengthening communities via the efforts of young people:

* Maintain consistency in making training available to library staff. Positive development is today's model for advancing the lives of young people. However, it takes time and effort to make sure adults have the wherewithal to make this happen. Professional development opportunities are pertinent if staff are to be a part of this progression.

* Recruitment efforts should continue focusing on staff in all age ranges. This study reflects that there is diversity in the age of staff, in which all noted positive experiences with youth. Each can offer the most important factor in the lives of youth - caring, supportive adult interaction.

* Staff should have more opportunities to work directly with youth. Those staff members with direct contact (whether it's reading to youth, helping them with a class assignment or serving as an advisor to the youth council) indicated more positive perceptions. Research has shown that positive interaction between youth and adults is a meaningful experience for both parties. This should occur within schools as well as through out-of-school experiences such as the library.

- Constructive time for youth should be considered. Those staff persons who indicated that their library had a youth advisory council had positive perceptions of youth and had more positive feelings about the level of support for youth within their communities. Providing youth with a chance to utilize their skills is an essential element of positive youth development. Moreover, when youth have the chance to engage in civic affairs, they become more in tune with their community while making a difference at the local level.

\section{References}

Allport, G.W. (1954). The nature of prejudice. New York: Doubleday Books.

American Library Association. (1999). Survey of Programs for School-Age Youth in Public Libraries. Technical report to the Dewitt Wallace-Reader's Digest Fund. Available on line at: http://ftrf.org/ala/yalsa/profdev/DeWittWallaceSurvey.pdf 
Benson, P.L. (1997). All kids are our kids: What communities must do to raise caring and responsible children and adolescents. San Francisco: Jossey-Bass.

Carnegie Council on Adolescent Development. (1992). A matter of time: Risk and opportunity in the non-school hours. New York, NY: Carnegie Corporation of New York.

Dryfoos, J.G. (2000). Evaluation of community schools: Findings to date. Coalition for Community Schools. Available online at: www.communityschools.org.

Eccles, J.S., \& Gootman, J.A. (Eds.). (2002). Community programs to promote youth development. Committee on Community-Level Programs for Youth. Washington, DC: National Academy Press.

Forum for Youth Investment. (2005). When school is out, museums, parks and libraries are in. Out-of-School Time Policy Commentary \#9. Washington, DC: the Forum for Youth Investment, Impact Strategies, Inc.

Gilliam, F.D., Jr. \& Bales, S.N. (2001, July). Strategic frame analysis: Reframing America's youth. (Social Policy Report, 15(3) of the Society for Research in Child Development). Available online at: http://www.srcd.org/sprv15n3.pdf.

Hewstone, M. (1996). Contact and categorization: Social-psychological interventions to change intergroup relations. In C. N. Macrae, C. Stagnor, \& M. Hewstone (Eds.), Foundations of stereotypes and stereotyping (pp. 323-368). New York:Guilford.

Jones, K.R. (2006). Relationships matter: A mixed methods evaluation of youth and adults working together as partners. Journal of Youth Development, 1(2). Available online at: http://www.nae4ha.org/directory/jyd/current issue.aspx

Jones, K.R. \& Perkins, D.F. (2006). Youth and adult perceptions of their relationships within community-based youth programs. Youth and Society, 38(1), 90-109.

Kelley, T. (2007, January 2). Lock the library: Rowdy students are taking over. The New York Times.

Lee, B.A., Farrell, C.R., \& Link, B.G. (2004). Revisiting the contact hypothesis: The case of public exposure to homelessness. American Sociological Review, 69, 40-63.

Little, P.M.D., Wimer, C., \& Weiss, H.B. (2008). Afterschool programs in the 21st century: Their potential and what it takes to achieve it. Harvard Family Research Project report: Cambridge, MA: Harvard Graduate School of Education.

Moellman, L.W., \& Tillinger, J.R. (2004). Civic spaces: Retooling public libraries to attract and engage teens after school. Afterschool Matters, 3, 28-36.

National Center for Educational Statistics. (1995). Services and resources for children and young adults in public libraries. U.S. Department of Education, Office of Educational Research and Improvement: Washington, DC. Available online at:

http://nces.ed.gov/surveys/frss/publications/95357/ 
Newman, S.A., Fox, J.A., Flynn, E.A., \& Christeson, W. (2000). America's afterschool choice: The prime time for juvenile crime or youth achievement and enrichment. Washington, DC: Fight Crime: Invest in Kids. Available at: http://fightcrime.org/reports/as2000.pdf

Pettigrew, T.F. (1998). Intergroup contact theory. Annual Review of Psychology, 49, pp. 65-85.

Pittman, K., \& Yohalem, N. (2002). Off the Shelf and into the Field: Making the Most of the National Research Council's New Report: Community Programs to Promote Youth Development. Washington, D.C.: Forum for Youth Investment. Available online at: http://www.forumforyouthinvestment.org/files/OffTheShelf.pdf

Rhodes, J. (2002). Stand by me: The risks and rewards of mentoring today's youth. Cambridge, MA: Harvard University Press.

Zeldin, S., Camino, L., \& Mook, C. (2005). The adoption of innovation in youth organizations: Creating the conditions for youth-adult partnerships. Journal of Community Psychology, 33(1), 121-135.

(C) Copyright of Journal of Youth Development $~$ Bridging Research and Practice. Content may not be copied or emailed to multiple sites or posted to a listserv without copyright holder's express written permission. However, users may print, download or email articles for individual use. 